\title{
Correction to: Lithostratigraphy of Devonian basinal mudrocks in frontier areas of northwestern Canada augmented with ED-XRF technique
}

Pavel Kabanov $^{1}$ (1) $\cdot$ Richard Vandenberg $^{1} \cdot$ Pierre Pelchat $^{2} \cdot$ Michelle Cameron $^{3} \cdot$ Keith Dewing $^{1}$

Published online: 19 June 2020

๑) Springer Nature Switzerland AG 2020

\section{Correction to: arktos}

https://doi.org/10.1007/s41063-020-00074-z

The original version of this article unfortunately contained a mistake. The presentation of Fig. 6 was incorrect.

The corrected Fig. 6 is placed in the following page.

The original article can be found online at https://doi.org/10.1007/ s41063-020-00074-z.

Pavel Kabanov

Pavel.Kabanov@canada.ca

1 Geological Survey of Canada, LMS, NRCan, Calgary, AB,

Canada

2 Geological Survey of Canada, LMS, NRCan, Ottawa, ON,

Canada

3 Bruker Elemental, Kennewick, WA, USA 


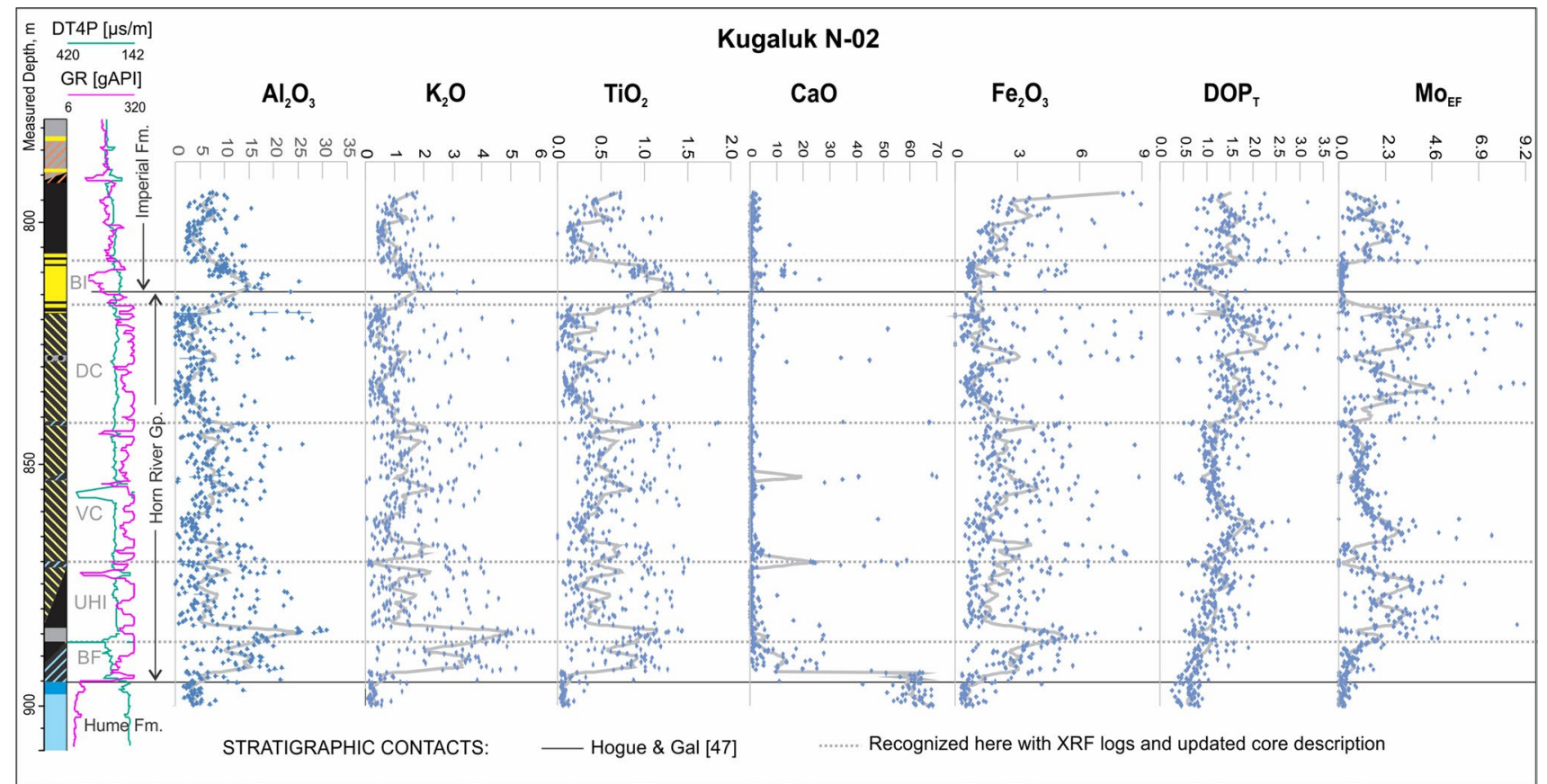

Fig. 6 Cored section of Horn River Group in Kugaluk N-02 with XRF proxies for terrigenous input $\left(\mathrm{Al}_{2} \mathrm{O}_{3}, \mathrm{~K}_{2} \mathrm{O}, \mathrm{TiO} 2, \mathrm{Fe}_{2} \mathrm{O}_{3}\right)$, carbonate content $(\mathrm{CaO})$, and anoxia $\left(\mathrm{DOP}_{\mathrm{T}}, \mathrm{Mo}_{\mathrm{EF}}\right)$. Error bars are only shown for $\mathrm{Al}_{2} \mathrm{O}_{3}$ data. Grey lines on logs are LOWESS regression with $\alpha$-tension $2.5 \%$. Data for $\mathrm{CaO}, \mathrm{Fe}_{2} \mathrm{O}_{3}, \mathrm{DOP}_{\mathrm{T}}$, and $\mathrm{MO}_{\mathrm{EF}}$ are

Publisher's Note Springer Nature remains neutral with regard to jurisdictional claims in published maps and institutional affiliations. truncated at 0.99 percentile. Pre-defined stratigraphic units [47] are labelled in black font. XRF-augmented units recognized in this study (grey font): $B F$ Bluefish, $U H I$ upper Hare Indian, $V C$ Vermillion Creek, $D C$ Dodo Canyon, and $B I$ basal Imperial sandstone. Legend for lithology is given in Fig. 4 